\section{Cureus}

\title{
Parkinsonism Sine Tremor - A Wrong Diagnosis
}

\author{
Ranjan Kumar singh ${ }^{1}$ \\ 1. Medical Doctor, District Hospital cum Civil Surgeon's Office Khagaria, India
}

$\square$ Corresponding author: Ranjan Kumar singh,dr_ranjankumarsingh@yahoo.com

Disclosures can be found in Additional Information at the end of the article

\section{Abstract}

A 50-year-old woman presented with rigidity of limbs, stooped posture, and mask-like face with monotonous speech. Preliminary clinical diagnosis of Parkinsonism sine (without) tremor was made. However, unresponsiveness of the patient's presenting features to the dopaminergic drug, levodopa, led us to re-examine the initial diagnosis. In particular, darkening of skin and low sodium level pointed to a possible diagnosis of adrenal gland failure. This was later confirmed by estimation of cortisol level (basal) as well as after synacthen injection.

Categories: Endocrinology/Diabetes/Metabolism, Neurology

Keywords: pseudoparkinsonism, adrenal failure, cortisol

\section{Introduction}

Features of Parkinsonism in conditions other than striatonigral disorder have been termed as secondary Parkinsonism or pseudoparkinsonism [1]. Due to dopamine receptor antagonist properties, antivertigo drug, cinnarizine, can induce hypokinesia, rigidity, drooling, and unsteady gait. These features mimicking Parkinsonism were initially referred to as pseudoparkinsonism; later these were grouped as drug-induced Parkinsonism (DIP) under the head of secondary Parkinsonism [1]. Resting tremor is conspicuously absent in secondary pseudoparkinsonism. Tremor in parkinsonism due to paralysis agitans remains unilateral to start with [1]. In contrast to Parkinson's disease, rigidity (in pseudoparkinsonism) happens due to paratonia, stooped posture, and gait occur; these are due to frontal ataxia, while hypokinesia develops from apraxic disorder. Drug-induced Parkinsonism (DIP) can be reliably distinguished from Parkinson's disease by dopamine transporter imaging (DAT-SPECT) [2]. We describe a case in which features mimicking DIP delayed the diagnosis of adrenal gland failure.

\section{Case Presentation}

Received 02/04/2014 Review began 02/05/2014 Review ended 03/21/2014 Published 03/22/2014

\section{C) Copyright 2014}

Kumar singh. This is an open access article distributed under the terms of the Creative Commons Attribution License CC-BY 3.0., which permits unrestricted use, distribution, and reproduction in any medium, provided the original author and source are credited.
A 50-year-old woman presented with stooped posture, rigidity, and hypokinetic movements. Resting tremor was absent. A clinical diagnosis of Parkinsonism without tremor was made, and she was prescribed the dopaminergic drug, levodopa, in a dose of $250 \mathrm{mg}$. b.d. After a month, she was back without any clinical improvement of Parkinsonism. Rather, she developed lassitude, fatigability, and restlessness. The diagnosis of Parkinsonism was reconsidered. Of note, the patient had dizziness for which she had been taking cinnarizine (an antihistaminic) in a dose of $50 \mathrm{mg}$. per day for the last three months.

Examination of the patient revealed sunken eyes, dry tanned skin, pulse rate of 100/mt, and a blood pressure of 100/70 mm of $\mathrm{Hg}$. Ophthalmoscopy revealed nothing of note. CBC showed mild lymphocytosis. Hemoglobin was $9.0 \mathrm{gm} / \mathrm{dl}$. Blood tests for renal function, diabetes, and 
liver function test were within normal range. Thyroid hormones were within normal limits. Serology for tuberculosis, hepatitis B virus, and HIV were negative or non-reactive. Chest x-ray and ultrasound of abdomen provided no fresh information. Findings of note were serum electrolytes (s/Na $\left.{ }^{+}-118 \mathrm{~m} \mathrm{~mol} / \mathrm{L}, \mathrm{s} / \mathrm{k}^{+}-4.8 \mathrm{~m} \mathrm{~mol} / \mathrm{L}\right)$ and serum cortisol level $60 \mathrm{n} \mathrm{mol} / \mathrm{L}$ at 9:00 AM. Diagnosis was confirmed by estimation of cortisol level $(70 \mathrm{n} \mathrm{mol} / \mathrm{L})$ half an hour after IM synacthen $(250 \mu \mathrm{gm})$. Treatment was started with prednisolone (a synthetic derivative of cortisol) in a dose of $5 \mathrm{mg}$. in the morning and $2.5 \mathrm{mg}$. in the evening. She was keeping well with the treatment. Her blood pressure increased up by $130 / 80 \mathrm{~mm} \mathrm{Hg}$, and electrolytes (s/ $\mathrm{Na}^{+}$ $140 \mathrm{~m} \mathrm{~mol} / \mathrm{L}$ and $\mathrm{s} / \mathrm{K}^{+} 4.5 \mathrm{~m} \mathrm{~mol} / \mathrm{L}$ ) were within normal range. Darkening of skin gradually faded. After three years, she developed cataracts in both eyes, possibly due to steroid therapy. There was no sign of Parkinsonism after stopping the cinnarizine.

\section{Discussion}

Clinical features of adrenal gland failure appear after destruction of $90 \%$ tissue of adrenal gland [3]. Recognition of early phase is challenging as initial symptoms are often misdiagnosed as chronic fatigue syndrome or depression [4]. In the case presented here, features of parkinsonism, which were due to antivertigo drug, cinnarizine, masked the diagnosis of adrenal gland failure. Cinnarizine, a piperazine derivative, has $\mathrm{D}_{2}$ receptor blocking property in the brain. Features of drug-induced Parkinsonism was initially thought to be paralysis agitans without tremor and levodopa was started. Nevertheless, treatment failed to ameliorate patient's hypokinetic movements and rigidity. Features of Parkinsonism following cinnarizine are not uncommon; however, it has been poorly reported. Further re-examination of patient revealed darkening of skin and lowered sodium level in the blood. Both features led us to suspect the diagnosis of adrenal gland failure. Darkening of skin is suggestive of chronic progression of adrenal gland failure. The etiological diagnosis of adrenal failure in the current case, in absence of tuberculosis and HIV, was probably autoimmune. However, a specific diagnosis was not established.

\section{Conclusions}

Cinnarizine-induced features mimicking Parkinsonism masked the diagnosis of chronic adrenal gland failure in this patient. However, absence of tremor and unresponsiveness to the dopaminergic drug, levodopa, led to a review of the diagnosis. The appearance of darkening of the skin and hyponatremia gave us the clue to possible diagnosis of chronic adrenal failure.

\section{Additional Information}

\section{Disclosures}

Human subjects: All authors have confirmed that this study did not involve human participants or tissue. Conflicts of interest: In compliance with the ICMJE uniform disclosure form, all authors declare the following: Payment/services info: All authors have declared that no financial support was received from any organization for the submitted work. Financial relationships: All authors have declared that they have no financial relationships at present or within the previous three years with any organizations that might have an interest in the submitted work. Other relationships: All authors have declared that there are no other relationships or activities that could appear to have influenced the submitted work.

\section{References}

1. Kurlan R, Rabin M: Pseudoparkinsonism: A review of a common nonparkinsonian hypokinetic movement disorder. Advances in Parkinson's Disease. 2013, 2:108-112.

2. Kagi G, Bhatia K, Tolosa E: The role of DAT-SPECT in movement disorders . J Neurol 


\section{Cureus}

Neurosurg Psychiat. 2010, 81:5-12.

3. Liddle, G: The adrenals. Text book of endocrinology. 6th ed . WB Saunders, Philadelphia; 1981.

4. Anand K, Thakur L: Cinnarizine induced parkinsonism. Neurol India. 1990, 88:411-14. 